\title{
Radiation Embrittlement Understanding for PLIM Activities at EC-JRC-IE
}

\author{
L. Debarberis, ${ }^{\text {a }}$ F. Sevini, ${ }^{\text {a }}$ B. Acosta, ${ }^{a}$ S. Pirfo, ${ }^{\text {a }}$ M. Bieth, ${ }^{\text {a }}$ H. Weisshaeupl, \\ K. Törrönen," A. Kryukov, ${ }^{\mathrm{b}}$ and M. Valoc

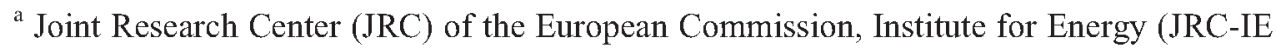 \\ Petten), Petten, the Netherlands \\ ${ }^{\mathrm{b}} \mathrm{RRC}-\mathrm{KI}$, Moscow, Russia \\ c VTT, Espoo, Finland
}

удК 539.4

\section{Радиационное охрупчивание корпусных сталей в рамках программы управления ресурсом АЭС}

\author{
Л. Дебарберис", Ф. Севини", Б. Акоста", С. Пирфо", М. Биет ${ }^{a}$, Х. Вайсхепл", \\ К. Торронен ${ }^{a}$, А. Крюков ${ }^{\sigma}$, М. Вало ${ }^{\text {в }}$
}

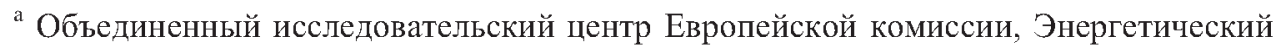
институт, Петтен, Нидерланды

${ }^{\sigma}$ Российский исследовательский центр, Москва, Россия

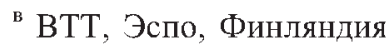

В рамках программы PLIM исследовано радиационное охрупчивание и механизмьл старения конструкционньх сталей внутрикорпусньх устройств реакторов с иелью оченки, прогнозирования и мониторинга ресурса ответственньх узлов АЭС. Изложень результать проекта SAFELIFE, объединяючего различные подходы к контролю ресурсол АЭС. Представлень результать радиационного охрупчивания модельных сплавов, проанализировань данньле испьтаний с использованием образиов-свидетелей, а также исследована надежность корпусных и других пипов сталей. Предложены перспективы развития разруиаюших и неразруиаюиих методов радиачионного охрупчивания материалов.

Ключевые слова: радиационное охрупчивание, старение, АЭС, корпусная реакторная сталь, химический состав.

1. Background. Nuclear electricity accounts for more than one third of the total EU needs, and the life distribution of the operating plants is such that in 2005 more than $70 \%$ of the plants will have passed the 20 -year lifetime and almost 30\% the 30-year age limit. In total, more than 100 LWRs in the EU and Associated States are producing more than $100 \mathrm{GWe}$.

In view of the secure and safe supply of electricity, aging of power plants is becoming of increasing concern in the EU as well as in the rest of the world. In fact, with increasing operational plant life approaching gradually the original

C L. DEBARBERIS, F. SEVINI, B. ACOSTA, S. PIRFO, M. BIETH, H. WEISSHAEUPL, K. TÖRRÖNEN, A. KRYUKOV, M. VALO, 2004 
design life, aging issues are arising. The list of issues is very long and research and development effort is required in order to understand and tackle them properly.

Such issues include: RPV embrittlement, core shrouds, upper and lower head cracking, sticking control rods, cracking in the control rod drive mechanism and upper head penetrations, reactor coolant piping issues, steam generator degradation, electric cable aging, and concrete aging.

An integrated view of aging mechanisms and optimization of PLIM (Plant Life Management) activities is promoted together with the prevention, performance and risk-informed-based approach.

In order to perform the PLIM task, an integration effort in the JRC has been undertaken and a new PLIM Action, SAFELIFE, has been launched for the 6th Framework Program (FP6), which integrates the efforts done in the past and the competencies of various European Networks. The effort is required in order to solve the problems summarized hereinafter. A complete list of NPP life management problems is not easy to draw, but anyhow a general agreement has been reached on several major items:

口 RPV embrittlement, effect of such elements as $\mathrm{Cu}, \mathrm{P}, \mathrm{Ni}, \mathrm{Mn}$, etc.

$\square$ Cracking of reactor internals shroud, cracking of bolts

$\square$ Thermal fatigue in piping

口 Integrity of dissimilar metal welds

口 Steam generator degradation cracking

$\square$ Aging of electric cables and concrete structures

2. The JRC Institute for Energy and the SAFELIFE Action. The JRC-IE with the AMES, NESC, ENIQ, NET, and SENUF European Networks and the information and competence within the TACIS Unit are playing a key role in solving such problems as plant life management, various aspects of: irradiation embrittlement, material degradation assessment and monitoring, surveillance, structural integrity, fracture mechanics studies, qualification of in-service inspection methodologies for crack detection, and recently, risk aspects. In addition, a new network, AMALIA, is in preparation in order to tackle the issues related to core internals and Irradiation Assisted Stress Corrosion Cracking (IASCC) phenomena. Some aspects of managing and mitigation of accidents, neutron beam methods for residual stress measurements, and other problems related to directives on pressure equipment are also dealt with.

For the 6th Framework Program, the JRC-IE has started the SAFELIFE Action. SAFELIFE is integrating various existing and designed JRC tasks and networks on the PLIM issues. PLIM is seen as a multi-disciplinary issue, which requires application of various involved disciplines ranging from crack detection, residual stress evolution, integrity assessment, degradation of material properties, IASCC, maintenance practices, etc.

The major objectives of the SAFELIFE projects are planned to be as follows:

$\checkmark$ Best practices: promotion, development, and dissemination:

- assessing neutron embrittlement (Ni, $\mathrm{Mn}, \mathrm{Cu}, \mathrm{P}$, etc.)

- annealing and re-embrittlement of WWER (PRIMAVERA)

- assessment of primary component integrity (Master Curve, dissimilar welds, large-scale benchmark tests, etc.) 
- thermal fatigue assessment

- residual stress evolution

- inspection qualification, risk-based approach and residual life

$\square$ Enhancing competencies/facilities in nuclear safety

- high-flux reactor, irradiation technology, rigs and neutron beams, JRC laboratories, reference materials.

- modeling, RPV cladding, etc.

$\checkmark$ Creation and implementation of the Training and Mobility Action:

- grant holders, visiting scientists, training workshops, Eurocourses, WEB, etc.

$\square$ Further exploit Networking (tool for Integration and Dissemination)

- completion of the projects GRETE, REDOS, PISA, FRAME, ATHENA, NURBIM, SPIQNAR, ENPOWER, INTERWELD, ADIMEW, THERFAT

- development of new ones coherent to SAFELIFE, using FP6 tools

- promotion and operation of the Network of Excellence/I.P. on PLIM

- IAEA co-operation

$\square$ Direct support to other Directorate Generals

During the EC's FP4 and FP5, JRC-IE has been co-ordinating and managing the major European Networks, namely, AMES, NESC, ENIQ, and also NET and their research activities in the area of nuclear plant life management.

$\square$ AMES deals with the problems of irradiation embrittlement, material degradation assessment and monitoring, surveillance, etc. [1-4].

$\square$ The NESC activity is dedicated to structural integrity, with a principal focus on fracture assessment [5-7]

$\square$ ENIQ considers risk-informed approaches to plant life management and the qualification of in-service inspection methodologies for defect detection and sizing [8].

$\square$ NET deals with the application of neutron-based testing for residual stress analysis, detection of defects, aging and irradiation damage, repair issues, etc.

$\square$ Relevant expertise on the subject is also available at the Institute for Energy at the Unit supporting the TACIS/PHARE programs (SENUF activity).

$\square$ AMALIA is the newest network dealing with internals issues and IASCC phenomena.

The Networks have brought together all key partners in Europe in various fields of aging, structural integrity, and inspection related to plant life management.

A large number of partnership projects in the area have been designed, promoted, and carried out in the last ten years. These European Networks have made a substantial contribution to the total effort in the field of nuclear plant life management through a large number of shared cost actions, thematic networks, concerted actions, and contribution-in-kind projects in the area.

For FP6, the JRC-IE has launched the SAFELIFE Action on PLIM [5] to integrate the efforts done in the past and the competencies of various European Networks (AMES, NESC, ENIQ, NET, AMALIA and SENUF) complemented by the information and competence developed within the TACIS programs. 
3. Example of Results in the Area of Radiation Embrittlement. In what follows we illustrate, as an example, some results obtained by AMES in the field of neutron-embrittlement. Figure 1 summarizes the results obtained from the model alloy project. The results showing the influence of nickel on irradiation embrittlement in synergy with copper and phosphorus are an important element for improved embrittlement-prediction formulas for high-nickel steels for RPVs like WWER-1000.
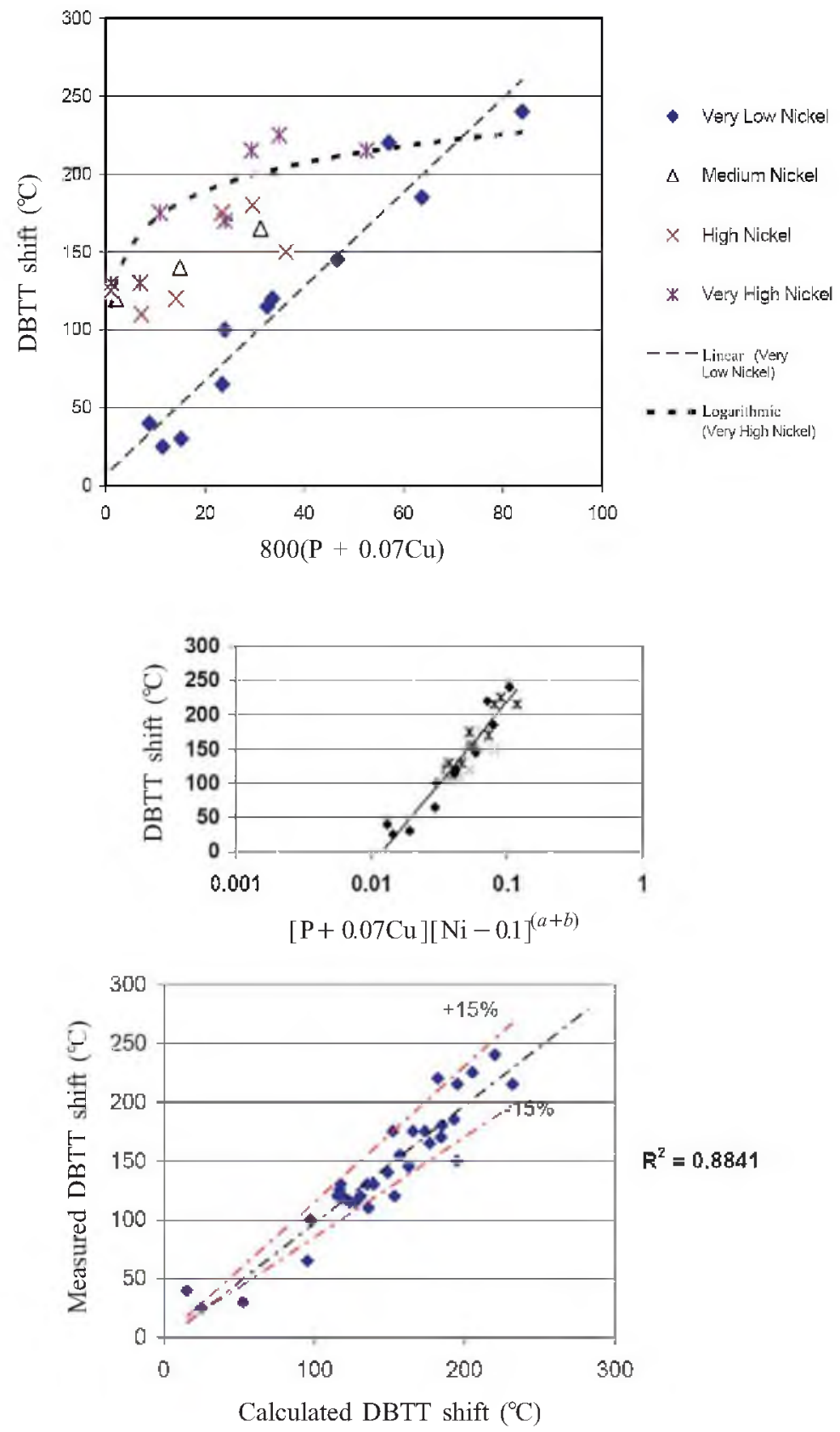

Fig. 1. Model alloys project; summary of results (DBTT is the ductile-to-brittle transition temperature). 
Another example of results is the understanding of the embrittlement kinetics in high-nickel commercial steels by the evaluation of WWER-1000 surveillance data and other relevant research data. The role of nickel for a broad fluence range is clear and plays a major role in the embrittlement, see Fig. 2.

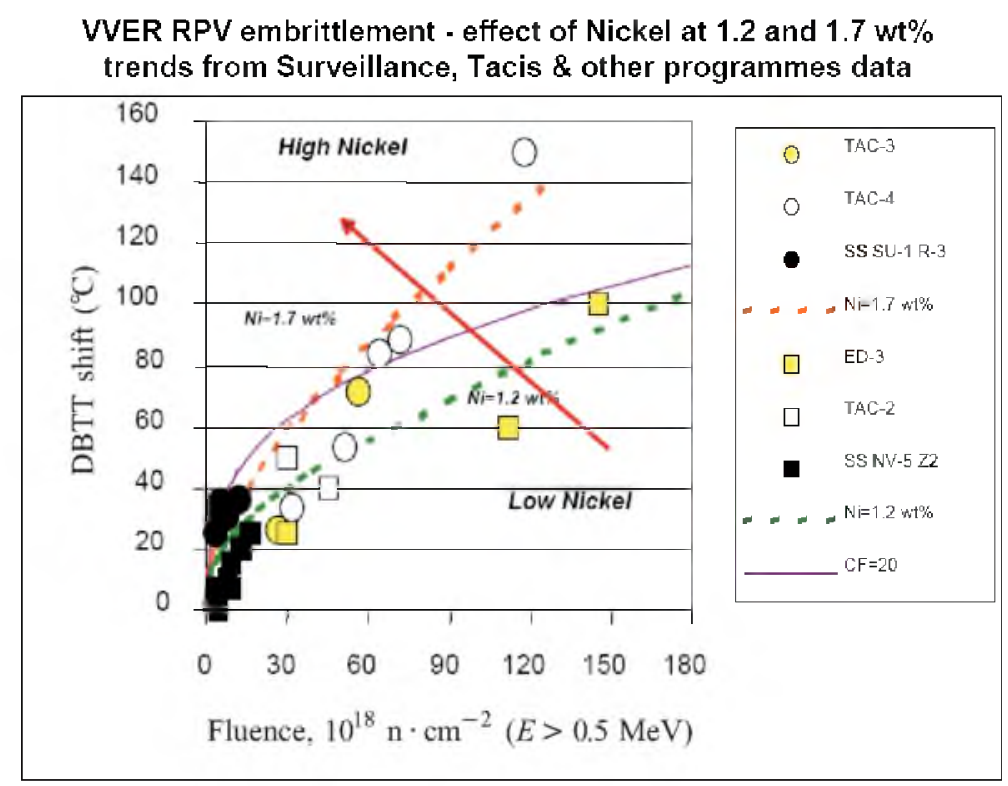

Fig. 2. Effect of nickel in high-Ni materials with low manganese.

In addition, the role of manganese in different WWER-1000 welds is targeted for additional irradiation embrittlement. Welds with the Mn content in excess of $\sim 0.9$ wt. $\%$, in combination with $\mathrm{Ni}$, exhibit an increased sensitivity to embrittlement, see Fig. 3.

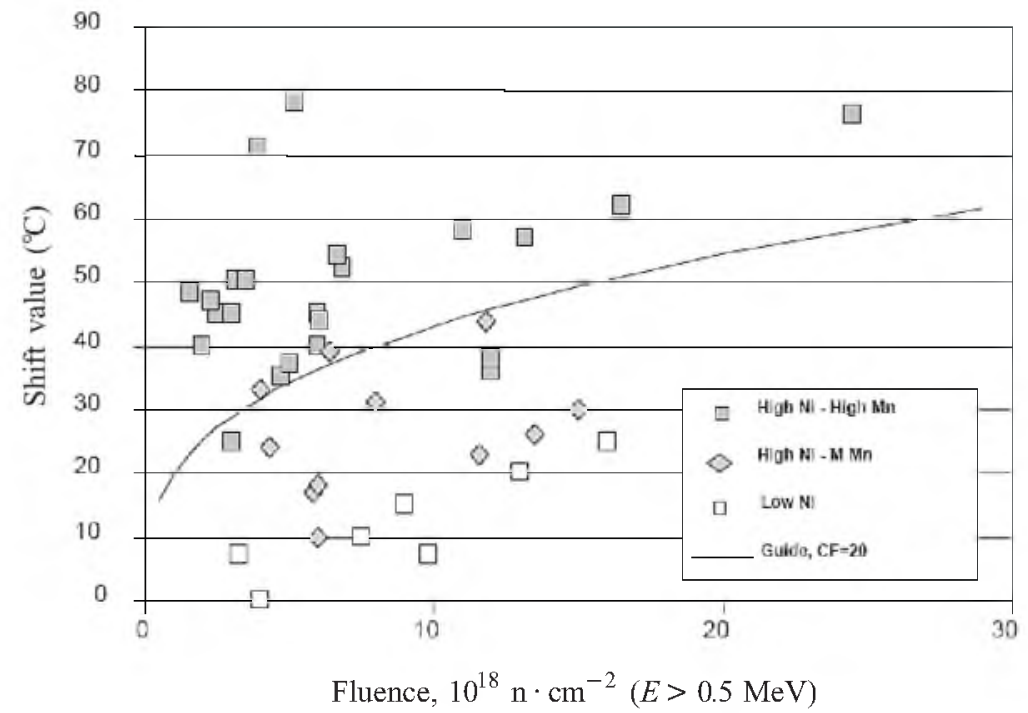

Fig. 3. The role of $\mathrm{Mn}$ in the embrittlement of high-Ni welds (WWER-1000 surveillance data). 
Recently, new data, both from destructive and non-destructive tests, have been obtained as well as important preliminary results. These are, for example, positron annihilation data on some selected irradiated alloys; high fluence irradiation data on model alloys, WWER-1000 reference steel data, analysis of samples irradiation under stress, etc. The analysis is ongoing and final results will be reported in the nearest future. These studies cover a wide range of issues related to radiation embrittlement, including the role of chemical composition $(\mathrm{P}$, $\mathrm{Cu}, \mathrm{Ni}, \mathrm{Mn}$ ) of steels and welds, the effect of irradiation dose and dose rate, irradiation temperature, annealing and re-embrittlement of pressure vessels of both western and Russian design. They are carried out within the framework of the SAFELIFE Action of JRC of the 6th Framework Program.

Conclusions. In FP6, the JRC-IE has launched the SAFELIFE Action on PLIM, which integrates the efforts done in the past and the competencies of various European Networks (AMES, NESC, ENIQ, NET, AMALIA and SENUF) complemented by the information and competence developed within the TACIS programs.

With SAFELIFE, the JRC plays a key role in the investigation of the problems of plant life management such as irradiation embrittlement, material degradation assessment and monitoring, surveillance, structural integrity, fracture mechanics studies, qualification of in-service inspection methodologies for crack detection and risk aspects.

Important results have already been obtained and additional results will become available from the large number of projects still carried out at present.

\section{Резиме}

У рамках програми PLIM досліджено радіаційне окрихчування і механізми старіння конструкційних сталей та реакторів із метою оцінки, прогнозування і моніторинга ресурсу відповідальних вузлів АЕС. Підсумовуються результати проекту SAFELIFE, що об'єднує різні підходи щодо контролю ресурсом АЕС. Представлено результати радіаційного окрихчування модельних сплавів, проаналізовано дані випробувань із використанням зразківсвідків, а також досліджується надійність корпусних та інших типів сталей. Запропоновано перспективи розвитку руйнівних і неруйнівних методів радіаційного окрихчення матеріалів.

1. F. Sevini, L. Debarberis, and M. Davies, "The European Network AMES," in: Proc. 6th Int. Conf. on Materials Issues in Design, Manufacturing, and Operation of NPP Equipment, St. Petersburg, Russia (2000).

2. A. Kryukov and L. Debarberis, "Achievements, open issues and developments on WWER RPV irradiation embrittlement assessment and AMES European Network strategy," in: IAEA Specialist Meeting on Irradiation Embrittlement, Madrid, PLIM+PLEX (1999).

3. L. Debarberis, F. Sevini, B. Acosta, et al., "Results of embrittlement studies on model alloys, reference steels, and RPV materials at JRC-IAM," in: Proc. 7th Int. Conf. on Materials Issues in Design, Manufacturing, and Operation of NPP Equipment, St. Petersburg, Russia (2002). 
4. L. Debarberis, "The effect of nickel, phosphorus, and copper in irradiation embrittlement of RPV steel model alloys," in: NATO Int. Workshop on RPV Embrittlement, Varna, Bulgaria (2000).

5. L. Debarberis, N. Taylor, A. Eriksson, et al., "An integrated view on plant life management; EC-JRC-IE projects and programs," in: Proc. IAEA PLIM Int. Conf. (Nov. 2002), Budapest (2002).

Received 26. 05. 2003 